\title{
Solid waste management in Koya city
}

\author{
Hawkar Ali Haji \\ Civil Engineering Department, Faculty of Engineering, \\ Koya University, Erbil, Iraq
}

\begin{abstract}
Since the beginning, humankind has been generating solid waste. The development of civilisation and the increase of population are the two main factors that have a direct impact on the growing amount of garbage. Thus, solid waste is a problematical issue that must be managed properly. This can help in protecting human health, the environment, and preserving natural resources. In Koya, one of the oldest waste disposal methods is used, which has several risks on the city. There are different possible ways for treating this problem and reducing the unwanted effects, for example, landfilling, incineration, recycling, reuse and reduction of waste. In this study, these solutions are described that each can replace the existing method depending on the economical and technical abilities.
\end{abstract}

Keywords: solid waste management, generation rate, sanitary landfilling, recycling, public health.

\section{Introduction}

Solid waste is defined as the unwanted or useless materials produced from the residential, industrial and commercial activities. It can be categorised as organic material, metal, glass, plastic and paper. The proportions of these contents depend on the area that generates the waste and the amount is different from one place to another. In 2007, the United States of America generated 260 million tons (before recycling) [1] which is around $30 \%$ of total solid waste generated by the entire world, while the population of the US does not exceed $4 \%$ of the global population. This is because it is one of the huge industrial countries in the world and mostly contributes the earth pollution and climate change.

In Koya, solid waste is managed by a company which is responsible for collecting rubbish and useless materials from residential and industrial areas then 
landfilling it randomly in a place which is around 5 kilometres away from the centre of the city. The disposal method and its being close to the city have left many disadvantages to the environment and public health of the city. For solving this issue, the alternative methods are illustrated and discussed.

The aim of this study is to illustrate how solid waste is managed in Koya with its risks, and investigation of the daily generation rate of waste that is produced by the residents of the city. Moreover, possible treatment methods are discussed that can replace the existing one in the city.

\section{Problem statement}

According to the data in 2013, the total mass of solid waste generates in Koya is ranged between 18 to 22 tons/day; the generation rate is estimated as $0.38 \mathrm{~kg} / \mathrm{capita} /$ day, while the population of the city is 53,450 [2]. So, the total amount will be around 600 tons in a month and 7200 tons in a year. This is really a huge quantity that may have several times danger than what is now present. Meanwhile, the development of the city and the increase of population are proportional to the raise in this amount.

Regarding the site view of waste disposal (see figure 1), a massive amount of this waste is contained from plastic bags and plastic bottles, while plastic is one of the most dangerous materials as its degenerating takes thousands of years but papers take a few weeks and organics just a few days.
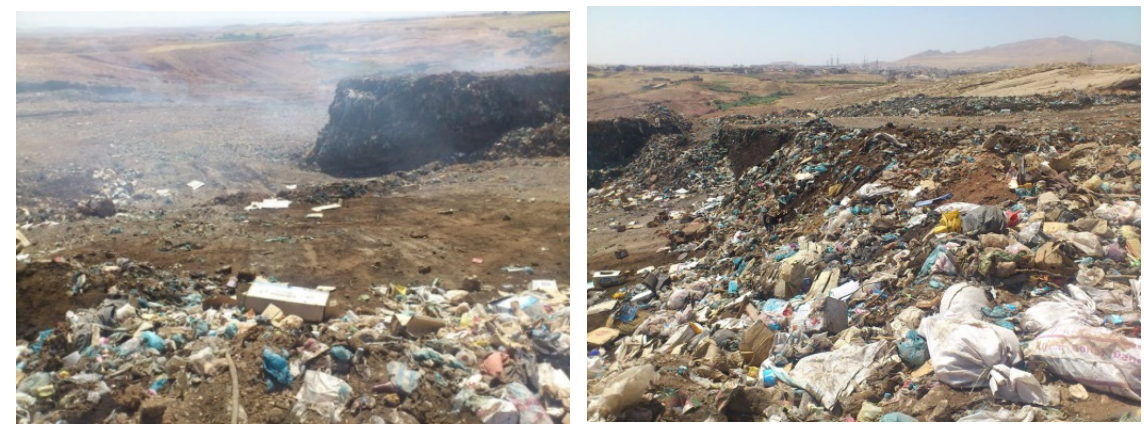

Figure 1: $\quad$ Waste disposal in Koya.

There are several possible methods that are implemented worldwide for managing solid waste; they can be drawn as a pyramid figure starting from less preferred to the most preferred (see figure 2). It begins from waste disposal (open dump and landfilling) to recycling, reuse and source reduction that locates in the top [3].

In Koya, open dumping method is used which is the least preferred and oldest method for waste disposal. It can be defined as an unplanned landfill with no leachate control, no access control, no cover and management. It is not a scientific way of waste disposal and refers to an uncovered site used for disposal of waste without environmental control (see figure 1). 


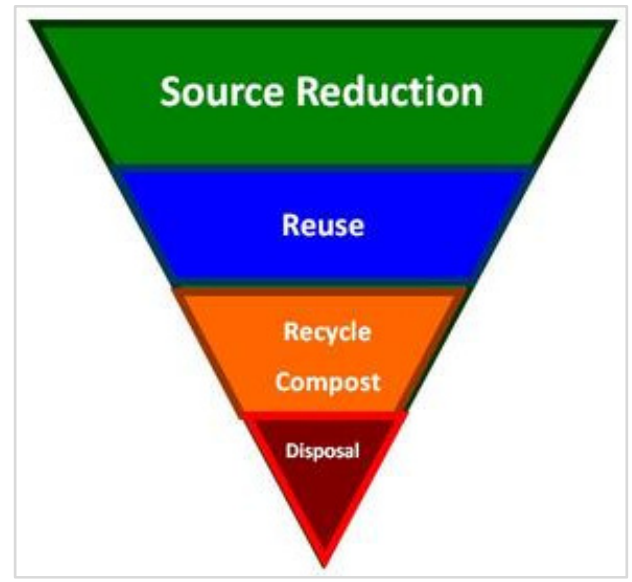

Figure 2: $\quad$ Solid waste management methods [3].

\section{Disadvantages of the open dumping method and negative impacts on Koya}

Waste disposal has left many unwanted effects for the environment of Koya and the health of residents in the city; they can be illustrated as follows:

1. In this method, the waste is untreated, uncovered, and not segregated.

2. Open dumps attract animals, flies and insects that annoys civilians living around.

3. The surrounding dumping area is heavily polluted and generates foul smell and unsightly appearance.

4. Loose waste is dispersed by the action of wind.

5. Drainage from leachate of the dumps contributes to the pollution of surface and ground water and also the rainwater run-off; this contaminates nearby land and water then resulting in spreading disease.

6. Open dump contributes in climate change by producing methane gas from the natural anaerobic decomposition of the organic wastes.

7. Artificial or natural burning occurs to the waste that releases smoke to the atmosphere and result in air pollution [4].

\section{Alternative methods for managing solid waste disposal}

Many alternative techniques can replace the existing method; they are described as follows:

\subsection{Landfilling (sanitary landfilling)}

Sanitary landfill is designed to effectively reduce the risks of waste disposal on the public health and environment. In this method, the waste is placed in an area 
that acts as a natural buffer between the waste and the ground. Moreover, water table in these zones should be in a law level and surface water must be absent so as to prevent the threat of water contamination.

In addition to the placement features, there are some other main points that are considered in the design, such as, the bottom and sides of landfills are covered with clay or plastic to keep the liquid of the waste and avoid escaping the leachate into the soil underneath. The collected leachate is pumped to the top for treatment unit, and some boreholes that called (monitoring wells) are dug for monitoring the quality of groundwater.

Sanitary landfills are divided into a series of individual cells of trash that daily waste spread through the cells and compacted for being smaller volume then a cover is applied. When the landfill has reached its capacity, it is capped with an impermeable seal which is typically composed of clay soil. Additionally, some sanitary landfills are used to recover energy from the gases, for instance methane, that are produced in the landfills. This occurs from the natural anaerobic decomposition of the organic wastes, and the collected gas can be used as an energy source for electric and heat. However, this process is very slow, a large volume of garbage are needed so that the energy recovery system will be successful [5].

Thus, sanitary landfills present the least environmental and health risk and the records kept can be a significant source of information for future use in waste management, however, the total cost of this method is high compared to other disposal methods (see figure 3).

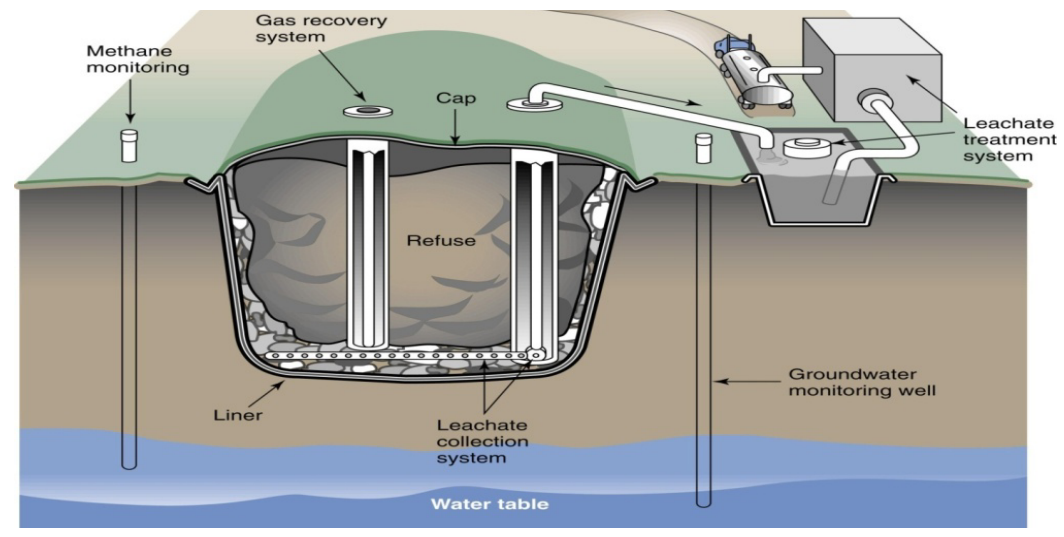

Figure 3: $\quad$ Sanitary landfill [5].

\subsection{Recycling}

Recycling can be defined as altering the waste to raw materials and using them in manufacturing new products. This process passes through three steps: sorting and collecting the recyclable garbage, creating raw material from the collected waste, and production of new items from the raw material. Sorting the recyclables can be done within the household and offices by the municipality or by the waste producer at recycling centres. The pre-sorting at the source requires 
public participation which may not be forthcoming if there are no benefits to be derived. Also a system of selective collection by the government can be costly. It would require more frequent circulation of trucks within a neighbourhood or the importation of more vehicles to facilitate the collection [6].

\subsection{Reuse and reduction}

Reuse of products and reduction of waste can be described as the method of waste prevention. They may reduce the demands for large scale treatment and disposal facilities. This can be done by manufacturing products with less packaging and encouraging the customers during shopping to bring their reusable bags (cloth bags) for packaging instead of new bags and using reusable plastic and glass containers. These methods require public awareness, training and educational programme to educate people about their role in the process.

According to data released by the United States Environmental Protection Agency (2003), around one trillion and 500 billion plastic bags are consumed worldwide each year; this means each two person consume a bag per day. Koya includes around 11,900 families [2]; if each family saves one bag in a day by using other reusable bags, the total daily saving will be 11,200 bags and more than 4,000,000 bags in a year. In this process, awareness of people and education is the only thing that needed for this effectively reduction of waste.

\section{Conclusion}

In conclusion, the traditional waste disposal in Koya leaves many risks on public health and the environment of the city. In order to reduce the amount of waste in Koya, some alternatives are described that each can replace the existing method and they are illustrated in table 1.

Table 1: $\quad$ Methods of waste disposal.

\begin{tabular}{|c|c|c|}
\hline Methods & Advantages & Disadvantages \\
\hline \multirow{3}{*}{ Sanitary landfill } & ${ }^{*}$ covering the waste & *requires proper planning and design \\
\hline & *leachate control & \multirow{2}{*}{$\begin{array}{c}\text { *the completed area may settle and } \\
\text { requires maintenance }\end{array}$} \\
\hline & *methane gas control & \\
\hline \multirow{3}{*}{ Recycling } & \multirow{3}{*}{$\begin{array}{l}\text { *providing unaccepted } \\
\text { environment } \\
\text { for the future }\end{array}$} & *expensive \\
\hline & & *all waste are not recyclable \\
\hline & & $\begin{array}{c}\text { *separation of materials from waste } \\
\text { difficult }\end{array}$ \\
\hline \multirow{3}{*}{$\begin{array}{l}\text { Reuse and } \\
\text { reduction }\end{array}$} & *economic & *it needs public awareness \\
\hline & *effective & \multirow[b]{2}{*}{ *controlling the production factories } \\
\hline & $\begin{array}{l}\text { *does not need technical } \\
\text { abilities }\end{array}$ & \\
\hline
\end{tabular}




\section{References}

[1] US EPA. 2007. Working Group Notes from the EPA Technical Workshop on Energy Efficient Servers and Datacenters. Santa Clara, CA: U.S. Environmental Protection Agency February 16.

[2] http://www.mop-krg.org/index.jsp?sid=1\&id=193\&pid=146

[3] http://www.wtbacc.com/wms/wms/en/wms-services/our-services/modernsanitary-landfill.html

[4] http://solid.gov.bb

[5] Christensen, T.H., R. Cossu, and R. Stegmann, eds. Sanitary Landfilling: Process Technology and Environmental Impact, Academic Press, London, England, 1989.http://en.wikipedia.org/wiki/Waste_management

[6] http://www.eia.doe.gov/kids/energyfacts/saving/recycling/solidwaste/landfill er.html 